\title{
The Effect of Average Length of Schooling, Life Expectancy and Economic Growth on Poverty in Banjarnegara Regency 2005-2019
}

\author{
By \\ Sri Sudaryati ${ }^{*}$, Abdul Aziz Ahmad, Suprapto \\ Faculty of Economics and Business, Universitas Jenderal Soedirman \\ ${ }^{*}$ Corresponding Author: sudaryaticapil@gmail.com
}

Submission: February 24, 2021; Accepted: March 29, 2021

\begin{abstract}
Banjarnegara Regency is one of the districts in the poverty red zone in the Central Java Province. In 2019, Banjarnegara Regency was in the $7^{\text {th }}$ (seventh) position of the 35 (thirtyfive) poorest regencies/cities with a poverty percentage of $14.76 \%$. This study purpose to analyze the effect of the average length of schooling, life expectancy and economic growth in the agriculture, fisheries and forestry sectors on poverty in Banjarnegara Regency in 2005-2019. The variables used are the average length of schooling, life expectancy and economic growth in the agricultural, forestry and fisheries sectors. The data used in this study is secondary data obtained from the Statistics Central Agency of Banjarnegara Regency. The results of this study are the average length of schooling and life expectancy have a negative and significant effect on poverty, while the economic growth in the agriculture, forestry and fisheries sectors does not have a significant effect on poverty. The implication of this research is that the local government of Banjarnegara Regency needs more intensive efforts from the local government to increase development in the education and health sectors with the expectation of encouraging wider learning opportunities, upraising education levels, and improving the quality of health of the population.
\end{abstract}

Keywords: Poverty, Average Length of Schooling, Life Expectancy, Economic Growth in The Agricultural, Forestry and Fisheries Sectors

\begin{abstract}
ABSTRAK
Kabupaten Banjarnegara merupakan salah satu Kabupaten yang berada dalam zona merah kemiskinan di wilayah Provinsi Jawa Tengah. Pada tahun 2019 Kabupaten Banjarnegara menempati posisi ke 7 (tujuh) dari 35 (tiga puluh lima) Kabupaten/Kota termiskin dengan persentase kemiskinan sebesar 14,76\%.. Penelitian ini bertujuan untuk menganalisis pengaruh angka rata-rata lama sekolah, angka harapan hidup dan pertumbuhan ekonomi sektor pertanian, perikanan dan kehutanan terhadap kemiskinan di Kabupaten Banjarnegara Tahun 2005-2019. Variabel yang digunakan adalah rata-rata lama sekolah, angka harapan hidup dan pertumbuhan ekonomi sektor pertanian, kehutanan dan perikanan. Data yang digunakan dalam penelitian ini merupakan data sekunder yang diperoleh dari Badan Pusat Statistik Kabupaten Banjarnegara. Metode analisis yang digunakan adalah regresi liniear berganda dengan data time series. Hasil dari penelitian ini adalah rata-rata lama sekolah dan angka harapan hidup berpengaruh negatif dan signifikan terhadap kemiskinan, sedangkan pertumbuhan ekonomi sektor pertanian, kehutanan dan perikanan tidak berpengaruh signifikan terhadap kemiskinan. Implikasi dari penelitian ini adalah pemerintah daerah Kabupaten Banjarnegara perlunya upaya yang lebih intensif dari pemerintah daerah untuk meningkatkan pembangunan di sektor pendidikan dan kesehatan dengan harapan mendorong kesempatan belajar yang lebih luas, menaikkan level pendidikan, serta memperbaiki kualitas kesehatan penduduk.
\end{abstract}


The Effect of Average Length .... (Sudaryati et all.)

Kata Kunci: Kemiskinan, Rata-rata Lama Sekolah, Angka Harapan Hidup, Pertumbuhan Ekonomi Sektor Pertanian, Kehutanan dan Perikanan

\section{INTRODUCTION}

Poverty is a fundamental problem in meeting basic needs in everyday life. However, the problem of poverty is not something that stands alone but is a result of not achieving economic development (Ishak et al, 2020). One of the goals of national development is to improve the performance of the economy so that it is able to create jobs and organize a decent life for all the people which will ultimately bring about the welfare of the Indonesian population. One of the national development goals is to reduce the poverty level. Poverty is one of the problems in the economy, so it must be resolved or at least reduced. The problem of poverty is indeed a complex and multidimensional problem. Therefore, poverty alleviation efforts must be carried out comprehensively covering various aspects of community life, and carried out in an integrated manner (Lendetariang et al, 2019).

One of the ways in which general welfare in Indonesia can be described is based on the level of poverty in Indonesia. There is a negative relationship between general welfare and poverty levels in Indonesia. The lower the poverty level, the higher the welfare of the population. (Star, 2018).

Faritz and Soejoto's research (2020) states that Economic Growth and average length of schooling have a significant negative effect on poverty in Central Java Province and Anggadini's research (2015) states that the Life Expectancy Rate (AHH) and GRDP show a negative sign and have a significant effect on poverty in the case of Central Sulawesi. Whereas in Nabawi Research (2020), the level of education did not have a positive effect on poverty in Malang. It was caused that education does not affect a person's preference to open their own business or to improve their economy. Also, people's productivity was not based on the level of education taken and GRDP did not have a positive effect on poverty is due to even or uneven economic growth in all elements of society.

Based on data from the Central Statistics Agency, Banjarnegara Regency is a poor area in Central Java Province. In 2019, Banjarnegara Regency is the 7 (seven) poor area of 35 (thirty-five) Regencies/Cities in Central Java Province. The percentage of poor people in Banjarnegara Regency in 2019 was $14.76 \%$. Judging from the relative position of Central Java Province, it is still above the average of Central Java Province of $10.80 \%$ and above the national poverty rate of $9.22 \%$. This condition shows the need to increase synergy in poverty reduction in the future to achieve a reduction in the poverty rate. The relative position of the percentage of poor people in Central Java Province can be seen in Picture 1.

Picture 1. Central Java Province Relative Position of Poverty Level (\%) in 2019

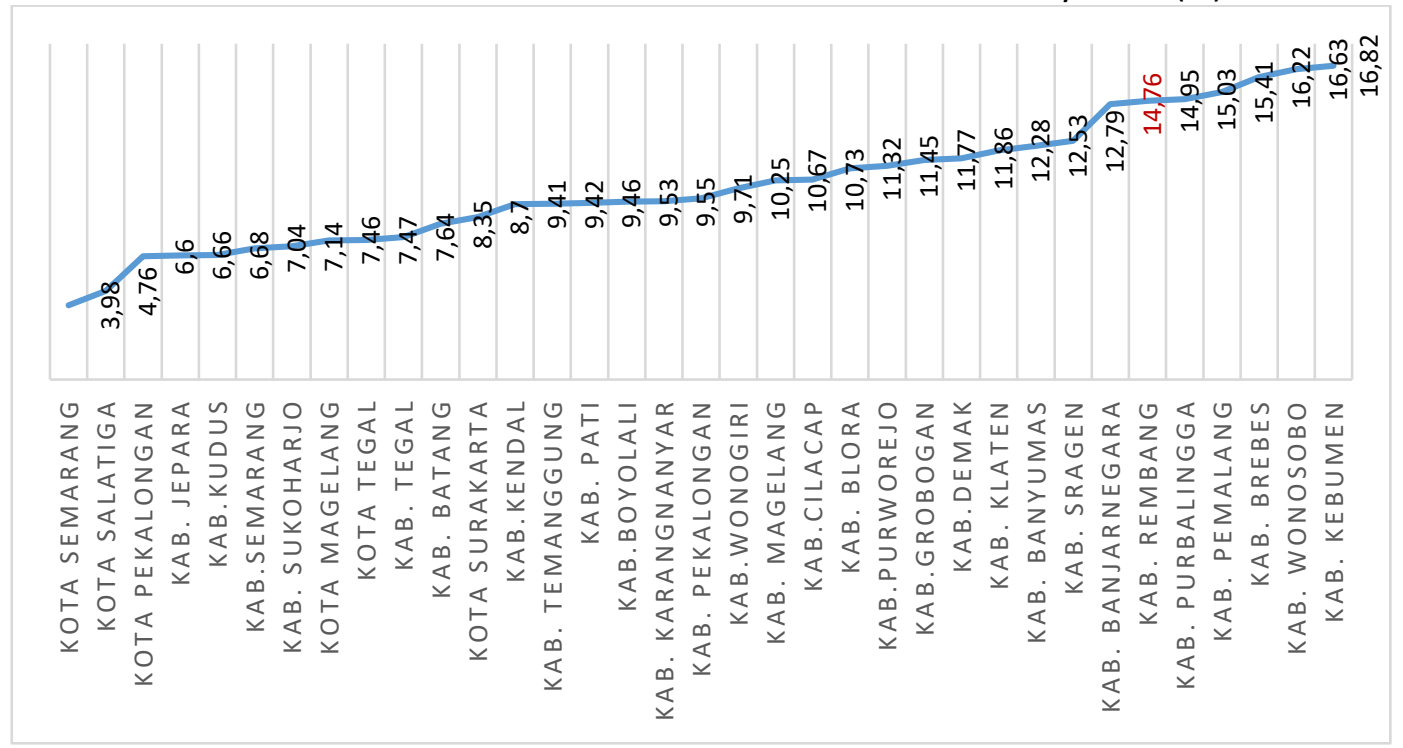

Source: Statistics Central Agency (BPS) of Central Java Province, 2020 
There are several studies that emphasize poverty reduction through development in several sectors. Sanz et al (2017) argue that poverty can be affected by the level of education. Ishak et al (2020) state that education tends to have a negative effect on poverty. Achievement of the average length of schooling for Banjarnegara Regency in 2019 is 6,50 and occupies the 33rd position out of 35 Regencies/Cities in Central Java Province, for the Achievement of the Life Expectancy Rate of Banjarnegara Regency in 2019 of 74,01 and occupies the 25th position of 35 Regencies/Cities in Central Java Province.

Health issues are also an important aspect of poverty prevention. Improved health will increase the productivity of the poor, where better health will increase working power, reduce days off and increase energy output. Therefore, good health will negatively affect the level of poverty (Arsyad, 2016: 307). This health factor is reflected in the low rate of life expectancy.

On the other hand, economic growth characterized by an increase in gross domestic product will drive poverty reduction. One of the proofs of this is from Anggadini's research (2015) where additional Gross Regional Domestic Products (GRDP) have a negative and significant impact on poverty in Central Sulawesi. This study uses a case in the Banjarnegra district. Banjarnegara is a district whose main sectors are agriculture, forestry and fisheries. This sector provided the largest contribution with the growth of the economic sector in 2019 at 3.53\%. This study specifically wants to detect whether economic growth in this sector has an important impact on poverty reduction in the Banjarnegra.

In this study, poverty is influenced by 3 (three) variables, is the average length of schooling, life expectancy and economic growth in the agriculture, forestry and fisheries sectors. The variable average length of schooling to describe the level of education, the variable life expectancy to describe the level of health and the variable of economic growth in the agriculture, forestry and fisheries sectors to describe the level of economic growth of the people of Banjarnegara Regency who are mostly farmers. This is a novelty in this research, which has not been carried out in previous studies that only examined macroeconomic growth.

The purpose of this study is to analyze the effect of the average length of schooling, life expectancy, and economic growth in the agricultural, forestry and fisheries sectors on poverty in Banjarnegara Regency in 2005-2019. Education is an investment for the formation of quality human capital, where both formal and non-formal education can play an important role in reducing poverty in the long term. Education provides knowledge, skills, values and behavior to improve quality of life, productivity and job opportunities. The higher a person's education level, the knowledge and expertise will also increase so that it will boost one's productivity and will increase income (Arsyad, 2016: 307)

Life expectancy is an indicator of poverty in terms of health. According to the Central Statistics Agency (2020), the Life Expectancy Rate is the estimated average number of years that a person can take during life. According to Arsyad (2016: 307) that better health will increase work power, reduce non-work days and increase energy output. Therefore, good health will negatively affect the poverty level.

Economic growth is defined as an increase in Gross Domestic Product/Gross National Income regardless of whether the increase is greater or less than the population growth rate or whether or not a change in economic structure occurs (Arsyad, 2016: 269). Economic growth only describes the aggregate, not partially. In fact, the process of high economic growth is not always balanced by an even distribution of income among economic actors (Arsyad, 2016: 282). The rapid growth of GNP per capita does not automatically increase the standard of living of the community because the trickledown effect of the benefits of economic growth for the poor does not occur (Arsyad, 2016: 280).

One of the characteristics of Indonesian poverty is poverty in rural areas and which is a factor in the high poverty rate because most of the rural population work in the agricultural sector, generally as agricultural laborers and unskilled laborers, so people's income is very low (Hasibuan et al, 2019). By referring to the theoretical rationale and based on empirical studies, the following hypothesis is proposed:

(1) H1: The variable Average Length of Schooling has a negative effect on poverty in Banjarnegara Regency in 2005-2019. 
(2) H2: The Life Expectancy Rate variable has a negative effect on poverty in Banjarnegara Regency in 2005-2019.

(3) H3: The variable of Economic Growth in the Agriculture, Forestry and Fisheries sectors has negative effect on poverty in Banjarnegara Regency in 2005-2019.

\section{METHODS}

This research was conducted with a quantitative approach, which is a research based on the philosophy of positivism, used to examine certain populations or samples, sampling techniques are generally carried out randomly, data collection uses quantitative/statistical data analysis research instruments in order to test the hypothesis that has been determined (Sugiyono, 2015: 14), where the dependent variable of this study is poverty using percent. The independent variables of this study include:

(1) Average length of school with units of years

(2) Life Expectancy Rate in years

(3) The Economic Growth in the agricultural, forestry and fisheries sectors in percent.

Secondary data were obtained from the Central Statistics Agency (BPS) Banjarnegara Regency. The type of data used in this study is secondary data from time series data over a period of 15 (fifteen) years, namely the years 2005-2019, which is quantitative data.

The analytical method used in this study is the multiple linear regression analysis method with the Ordinary Least Square (OLS) approach. The analytical tools used in this study are SPSS 24 and Microsoft Excel 2013. Multiple Linear Regression Analysis is a statistical technique for modeling and investigating the effect of several independent variables on one response variable (dependent variable) (Tri Basuki \& Prawoto), 2017: 45).

In analyzing the effect of the average length of schooling, life expectancy and economic growth in the agriculture, forestry and fisheries sectors on poverty in Banjarnegara District 2005-2019, the following model was used:

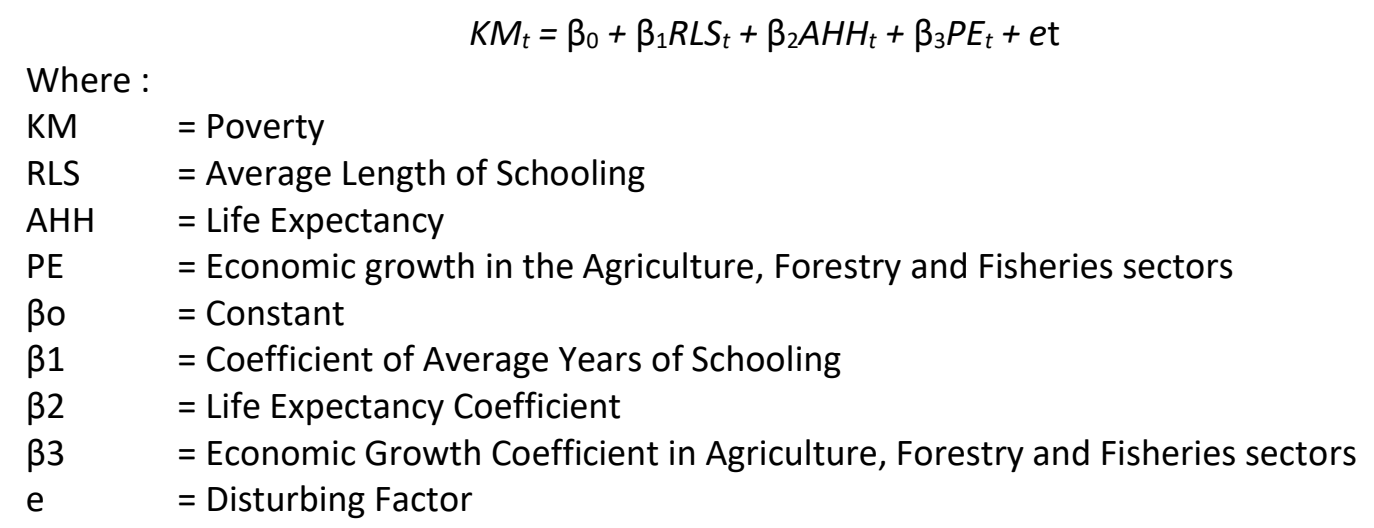

\section{RESULTS AND DISCUSSIONS}

The poverty level of Banjarnegara Regency from 2005-2019 has decreased, but seen from the relative position of Central Java Province, it is still above the average of Central Java Province and the national poverty level. In the poverty rate period of $14.76 \%$, the number of poor people in Banjarnegara Regency in 2019 was 136,100 people. When compared with the number of poor people in Central Java Province in the same year of 3,679,400 people, Banjarnegara Regency contributed $3.7 \%$ of the total number of poor people in Central Java Province in 2019.

The average length of schooling in Banjarnegara Regency from 2005 to 2019 has increased by 0.71 . However, in 2010 there was a decrease in the average length of schooling from 6.20 to 5.84 and subsequently continued to increase until 2019 amounted to 6.50. The average length of school for Banjarnegara Regency in 2019 is in the 33rd position of 35 districts / cities in Central Java Province.

The Life Expectancy Rate of Banjarnegara Regency in general and specifically tends to increase from year to year. In 2019, when compared to the achievements in 2018, there was an increase of 0.1, 
from 73.91 to 74.01 . When compared to the achievement of the Life Expectancy Rate at the Provincial Level of Central Java, Banjarnegara Regency ranks 25th.

Economic growth from the agricultural, forestry and fisheries sectors in Banjarnegara Regency fluctuates. The lowest economic growth in the agricultural, forestry and fisheries sectors was in 2014, namely $0.76 \%$ and the highest in 2011 was $5.46 \%$.

The results of the regression equation to determine the average length of schooling, life expectancy and economic growth in the agriculture, forestry and fisheries sectors against poverty can be seen in the following table 1 , where the independent variable is the natural logarithm of poverty (LnKM).

Table 1. Regression Output

\begin{tabular}{lccc}
\hline \multicolumn{1}{c}{ Variable } & Coefficient & t-stat & P-value \\
\hline (Constant) & 25.507 & 12.675 & 0.000 \\
LnRLS & -2.286 & -4.490 & 0.001 \\
LnAHH & -4.317 & -8.000 & 0.000 \\
LnPE & 0.047 & 1.376 & 0.196 \\
\hline
\end{tabular}

in formal form, the table can be written in the equation:

$\operatorname{Ln} K M_{\mathrm{t}}=25.507-2.286 R L S_{\mathrm{t}}-4 ., 317 A H H_{\mathrm{t}}+0.047 P E_{\mathrm{t}}$

The average length of schooling has a coefficient value of $-2,286$, which means that the average length of schooling has a negative effect on poverty. This means that if the average length of schooling increases by $1 \%$, the poverty rate will decrease by $2.286 \%$. This influence is in accordance with the theory and is significant on statistics. This is consistent with the research of Bintang (2018), Faritz and Soejoto (2020), that the average length of schooling has a significant negative effect on poverty in Central Java Province.

Education is an investment for the formation of quality human capital, where both formal and non-formal education can play an important role in reducing poverty in the long term. Education provides knowledge, skills, values and behavior to improve quality of life, productivity and job opportunities. The higher a person's education level, the knowledge and expertise will also increase so that it will boost one's productivity and will increase income (Arsyad, 2016: 307).

Average Length of Schooling (RLS) has a coefficient of $-2,286$. This figure indicates that a $1 \%$ increase in school years will have the potential to reduce poverty by $2.286 \%$.

For the effect of the second independent variable, Life Expectancy Rate (AHH) has a coefficient value of $-4,317$ which means that Life Expectancy has a negative effect on poverty. This means that if the Life Expectancy Rate increases by $1 \%$, the poverty rate will decrease by $4,317 \%$. This is in accordance with the research of Anggadini (2015), Bintang (2018), Ginting (2020), Ishak et al (2020) that the Life Expectancy Rate (AHH) shows a significant negative effect on poverty.

Economic growth in the agricultural, forestry and fisheries sectors has a coefficient value of 0.047 which means that the economic growth of the agricultural, forestry and fisheries sectors has a positive effect on poverty. If Economic Growth increases by $1 \%$, the poverty rate will increase by $0.047 \%$. Therefore, the economic growth variable has a significant value greater than the significance level $(0.196>0.05)$, so it can be concluded that the economic growth variable in the agriculture, forestry and fisheries sectors has no significant effect on the poverty level in Banjarnegara Regency.

This is in accordance with Nabawi Research (2020), that GRDP does not have a positive effect on poverty because economic growth is uneven or does not spread across all elements of society and results in inequality and Bintang's research (2018) that GRDP has a positive and significant effect on levels poverty in Central Java Province and research by Lendetariang et al (2019) that economic growth has no influence on the poor in Sangihe Islands Regency.

To detect deeper statistical tests of the model, the following classical assumptions are tested:

\section{Multicollinearity}

To detect the presence or absence of multicollinearity, it can be seen from the Variance Inflation Factors (VIF) and Tolerance. The guideline for a regression model that is free of multicollinearity is to 
have a tolerance number close to 1 . The VIF limit is 10 , if the VIF value is below 10 , then there is no multicollinearity symptom (Gujarati, 2012: 432).

Table 2. Multicollinearity test with VIF Method

\begin{tabular}{cc}
\hline Variable & Cetered VIF \\
\hline LnRLS & 1.492 \\
LnAHH & 1.464 \\
LnPE & 1.383 \\
\hline Dependent Variable: $L n \_K M$
\end{tabular}

From the table above it can be seen that the VIF value on the average length of schooling (RLS) is 1,492, the Life Expectancy Rate (AHH) is 1,464 and the Economic Growth of the Agriculture, Forestry and Fisheries (PE) Sector is 1,383. The results of the VIF value of all the independent variables are less than 10 , so it can be stated that there is no problem or freedom from multicollinearity.

\section{Autocorrelation}

Autocorrelation is the correlation (relationship) that occurs between the members of a series of observations arranged in a time series. This autocorrelation shows the relationship between successive values of the same variables. The statistical test for the autocorrelation test uses the Durbin Watson value. The test results show the DW test value of 1.423. Although the results of this test show that the DW test results are in an area of uncertainty, statistically $i$ tis not in a positive or negative autocorrelation condition.

\section{Normality}

Normality test is performed using Kolmogorov Smirnov (KS), this test determines whether the data distribution is normal or not seen through a comparison of significance values. If the resulting significance value $>0.05$, the data distribution can be said to be normal. Conversely, if the resulting significance value $<0.05$, the data is not normally distributed.

The results of the Kolmogorov Smirnov (KS) statistical test showed that the P-value of KS statistic test is 0.2 . The result of the normality test shows a P-value of KS is greater than $\alpha 0.05$ which it means that the data is normally distributed statistically.

\section{Heteroscedasticity}

Heteroscedasticity test aims to test whether in the regression model there is an inequality of variance from one residual observation to another. The results of the heteroscedasticity test using the Glejser method show the results as shown in Table 3.

Table 3. Output from Glejser Heterocedasticity Test

\begin{tabular}{lccc}
\hline \multicolumn{1}{c}{ Variable } & Coefficient & t-stat & P-value \\
\hline (Constant) & 1.382 & 1.675 & 0.122 \\
LnRLS & 0.309 & 1.483 & 0.166 \\
LnAHH & -0.445 & -2.011 & 0.069 \\
LnPE & 0.005 & 0.394 & 0.701 \\
\hline
\end{tabular}

Dependent Variable: abs (u)

The significance of each independent variable indicates the level of P-value for each coefficient are more than $\alpha(5 \%)$, therea ara 0.166 for the average length of schooling (RLS), 0.069 for life expectancy (AHH), and 0.701 for economic growth. This figure shows that this study is statistically free from heteroscedasticity effect on model.

Further test results for hypothesis testing and measurement of the value of determination, the following results are obtained

\section{F Test}

The basic $\mathrm{F}$ statistical test shows whether all the independent variables included in the model have a joint influence on the dependent variable. The estimated model is suitable to be used to explain the effect of the independent variables to the dependent variable. If after testing the P-value of $F$ test is 
smaller than the error rate (alpha) 0.05 (which has been determined), it can be said that the estimated regression model is statistically significant effect, whereas if the P-value of $F$ Test is greater than the error rate of 0.05 , it can be said that the estimated regression model is not statistically significant effect.

The results of the $F$ test can be obtained a value of 56,666 . The $F$ test identic to $P$-value test with value of 0.000 and $i$ tis smaller than the significance level of 0.05 . It can be concluded that the estimated regression model is statistically significant effect, where the effect of Average School Years (RLS), Life Expectancy (AHH) and Economic Growth in the Agricultural, Forestry and Fisheries (PE) Sectors collectively have a statistical effect on changes in Poverty variable (KM)

\section{Regression Coefficient Test (t test)}

The $t$ test is used to show how far the influence of one independent variable on the dependent variable by assuming the other independent variables are constant. The formulation of the one tailed test hypothesis in the $t$ statistical test for all independent variables are:

Ho: $\beta 1 \geq 0$, meaning that the independent variable partially does not have a significant effect on the dependent variable.

Ha: $\beta 1<0$, meaning that the independent variable partially has a significant effect on the dependent variable

For the first variable, the Average Length of School variable (RLS) has a t-statistic value of $-4,490$ with a P-value of 0.001 . This figure means that there is a negative and significant effect of the RLS variable on poverty $(\mathrm{KM})$. Thus, hypothesis $0(\mathrm{Ho})$ is rejected and the alternative hypothesis $(\mathrm{Ha})$ is accepted. For the second variable, the Life Expectancy Rate variable $(\mathrm{AHH})$ yields $\mathrm{t}$ statistical information of $-8,000$ with a P-value of 0,000 . This value means that $\mathrm{AHH}$ has a negative and significant effect on poverty (KM). It can also be claimed that hypothesis $0(\mathrm{Ho})$ is rejected and the alternative hypothesis $(\mathrm{Ha})$ is accepted. For the third variable, the results are different from the first and second independent variables. The Economic Growth variable (PE) in the Agriculture, Forestry and Fisheries sectors produces a statistical $t$ value of 1.376 with a P-value of 0.196 . This statistical value does not meet the criteria of the research hypothesis which indicates a moderate negative effect of economic growth on poverty and also the level of statistical significance. It can be said that hypothesis $0(\mathrm{Ho})$ is accepted and the alternative hypothesis $(\mathrm{Ha})$ is rejected.

\section{Coefficient of Determination $R^{2}$}

The coefficient of determination explains the variation in the influence of the independent variables on the dependent variable. The calculation results the value of the coefficient of determination symbolized by $R^{2}$ (R-Square) of 0.939 which means that the variables of the Average Length of Schooling (RLS), Life Expectancy (AHH) and Economic Growth in the Agriculture, Forestry and Fisheries $(\mathrm{PE})$ sectors contribute to the dependent variable, and shows the percentage value of the independent variable under study that affects the poverty variable by 93.9 percent while the remaining 6.1 percent is explained by other variables outside of this study.

\section{CONCLUSION}

Based on the research above, the variables of average length of school and life expectancy have a negative and significant effect on poverty. This is in accordance with Arsyad that the higher the level of education and health of a person, the knowledge, skills and work power will increase so that it will boost one's productivity and will increase income.

The variables of economic growth in the agriculture, forestry and fisheries sectors do not have a significant effect on poverty in Banjarnegara Regency. This result indicates that the economic growth of the agricultural, forestry and fisheries sectors is not evenly distributed across all economic actors in the agricultural, forestry and fisheries sectors. Economic growth that is not followed by equal distribution will result in economic inequality.

Policy makers at the Banjarnegara Regency Government in formulating budget policy priorities to prioritize development activities related to average length of schooling and life expectancy which 
can be implemented through programs and activities at the Education, Youth and Sports Department, Health Department, Agriculture, Fisheries and Food Security Department as well as Department supporting community economy related to support the success of poverty alleviation in Banjarnegara Regency.

\section{REFERENCES}

Anggadini, F. (2019). Analisis Pengaruh Angka Harapan Hidup, Angka Melek Huruf, Tingkat Pengangguran Terbuka dan Pendapatan Domestik Regional Bruto Perkapita Terhadap Kemiskinan Pada Kabupaten/Kota Di Provinsi Sulawesi Tengah Tahun 2010-2013, e-Jurnal Katalogis, 3 (7), 40-49.

Arsyad, L (2016). Ekonomi Pembangunan. Edisi Kelima. Yogyakarta, UPP STIM YKPN

Badan Pusat Statistik (BPS) Kabupaten Banjarnegara. (2020). Angka Kemiskinan Kabupaten Banjarnegara 1996-2017, Retrieved from https://banjarnegarakab.bps.go.id/dynamictable/ 2016/03/21/3/angka-kemiskinan-kabupaten-banjarnegara-tahun-1996-2017.html

Badan Pusat Statistik (BPS) Kabupaten Banjarnegara. (2020). Indeks Pembangunan Manusia Kabupaten Banjarnegara 2010-2019, Retrieved from https://banjarnegarakab.bps.go.id/ statictable/2015/11/24/4/indeks-pembangunan-manusia-kabupaten-banjarnegara-metodebaru-tahun-2010-2019.html

Badan Pusat Statistik BPS) Kabupaten Banjarnegara. (2020). Laju Pertumbuhan PDRB Kabupaten Banjarnegara Menurut Lapangan Usaha Tahun 2010-2019. Retrieved from https://banjarnegarakab.bps.go.id/statictable/2020/02/28/129/laju-pertumbuhan-pdrbkabupaten-banjarnegara-menurut-lapangan-usaha-persen-2010---2019.html

Badan Pusat Statistik (BPS) Provinsi Jawa Tengah. (2021), Indeks Pembangunan Manusia Metode Lama. Retrieved from https://ipm.bps.go.id/data/provinsi/metode/lama/3300.

Badan Pusat Statistik (BPS) kabupaten Banjarnegara. (2020). Banjarnegara Dalam Angka, Banjarnegara, Badan Pusat Statistik.

Bintang, A.B.M. (2018). Pengaruh PDRB, Pendidikan, Kesehatan, Dan Pengangguran Terhadap Tingkat Kemiskinan di Jawa Tengah (2011-2015). Media Ekonomi dan Manajemen, XXXIII (1), 20-28

Faritz, M.N. \& Soejoto A. (2020). Pengaruh Pertumbuhan Ekonomi dan Rata-Rata Lama Sekolah Terhadap Kemiskinan di Provinsi Jawa Tengah. JUPE 8 (1), $16-21$

Ginting, A.L. (2020). Dampak Angka Harapan Hidup dan Kesempatan Kerja Terhadap Kemiskinan. Economics Social and Development Studies, VII(1), 42-61.

Gujarati, D \& Porter, D. (2012). Basic Econometrics. Translation book of Mangunsong, R. C.: Dasardasar Ekonometrika, Edisi Kelima Buku Kedua, terjemahan. Jakarta: Salemba Empat

Hasibuan, S.N., Juanda, .B \& Mulatsih, S. (2019). Analisis Sebaran dan Faktor Penyebab Kemiskinan di Kabupaten Bandung Barat. Jurnal Agribisnis Indonesia, VII (2), 79-91.

Ishak, R.A., Zakaria, J. \& Arifin, M. (2020). Pengaruh Pertumbuhan Ekonomi, Pendidikan dan Pengangguran Terhadap Tingkat Kemiskinan di Kota Makassar. Paradoks Jurnal Ilmu Ekonomi, $3(2), 41-53$.

Lendentariang, D., Emka, D.S.M. \& Tolosang, K.D. (2019). Pengaruh Pertumbuhan Ekonomi, Tingkat Pengangguran dan Jumlah Penduduk Terhadap Kemiskinan di Kabupaten Kepulauan Sangihe. Jurnal Berkala Ilmiah Efisiensi. 19 (2), 23-34.

Nabawi, H. (2020) Pengaruh Jumlah Penduduk, Tingkat Pendidikan dan PDRB Terhadap Kemiskinan di Kota Malang. OECONOMICUS Journal of Economics, 4 (2), 104-117

Sanz, R., Peris, J.A, \& Escámez, J. (2017). Higher education in the fight against poverty from the capabilities approach: The case of Spain. Journal of Innovation \& Knowledge, 2(2), 53-66.

Sugiyono. (2015). Metode Penelitian Pendidikan Pendekatan Kuantitatif, Kualitatif dan R\&D. Yogyakarta, Alfabeta. 